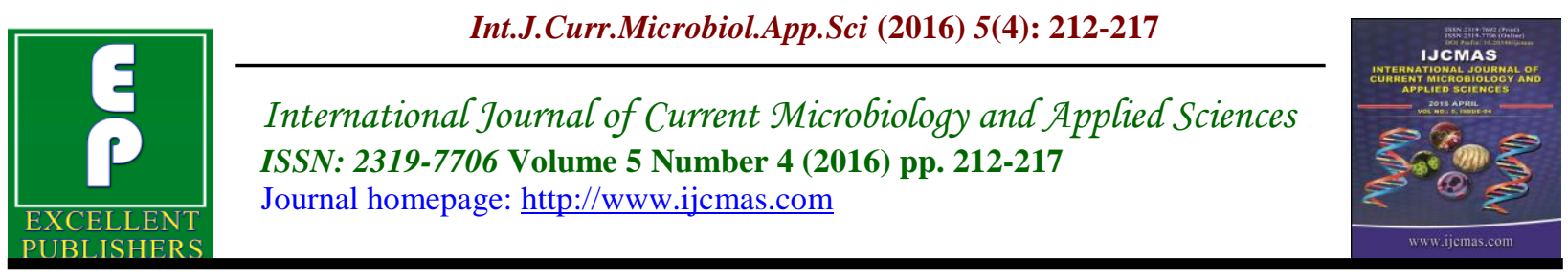

Original Research Article

http://dx.doi.org/10.20546/ijcmas.2016.504.026

\title{
Genetic Diversity Studies in Tomato (Solanum lycopersicum L.) Under Protected Conditions
}

\author{
S. L. Lekshmi* and V. A. Celine \\ Department of Olericulture, College of Agriculture, Kerala Agricultural University, \\ Vellayani, Thiruvananthapuram-695522, Kerala, India \\ *Corresponding author
}

\begin{abstract}
A B S T R A C T
Keywords

Tomato, clusters, D2 analysis, Germplasm, diversity.

\section{Article Info}

Accepted:

15 March 2016

Available Online:

10 April 2016

Forty tomato genotypes were evaluated in randomized block design with three replications at College of Agriculture, Vellayani, Kerala during October 2013 to April 2014. A wide range of variation was observed among the characters studied which have a great interest for polyhouse tomato breeding. Genetic divergence analysis was carried out using Mahalanobis $\mathrm{D}^{2}$ statistics and the 40 tomato genotypes were grouped into eight clusters. Cluster I was the largest cluster with twenty four genotypes followed by cluster II with ten genotypes and all other clusters were solitary. The highest intracluster distance was noticed in cluster II followed by cluster I. The highest intercluster distance was observed between clusters VII and VIII, followed by clusters IV and VIII. Lycopene content and truss per plant had maximum contribution towards total divergence followed by fruit length, fruit weight and yield per plant.
\end{abstract}

\section{Introduction}

The aim of protected cultivation is to achieve independence of climate and weather and to allow crop production in areas where the natural environment limits or prohibits plant growth. In the present scenario of perpetual demand of vegetables and drastically shrinking land holdings in the country, it is the best drudgery less approach for better resource management. Tomato, (Solanum lycopersicum L.) the globally leading popular vegetable belonging to Solanaceae family is being extensively cultivated under protected conditions and gives higher returns. India enjoys the second position in tomato production next to China, with a share of $11.50 \%$ of world production. India has an area of 1.20 Mha, total production of 19.40 $\mathrm{Mt}$ and a productivity of $16.10 \mathrm{t} \mathrm{ha}^{-1}$ for tomato. Being an important vegetable crop, there is a need to develop tomato varieties and hybrids suitable to specific agroecological conditions and also for specific end use. One of the present techniques of measuring genetic divergence is by Mahalanobis's $\mathrm{D}^{2}$ statistic. 
Hybridization between divergent parents is likely to produce wide variability and transgressive segregation with high heterotic effects. $D^{2}$ analysis is a useful tool in quantifying the degree of divergence between biological population at genotypic level and to assess relative contribution of different components to the total divergence, both at the inter- and intra-cluster levels. The progenies derived from diverse parents are expected to show a broad spectrum of genetic variability and provide better scope to isolate superior recombinants. Therefore, genetically diverse genotypes per genotypes should be used in a hybridization programme to get superior recombinants.

\section{Materials and Methods}

The experimental material consisted of 40 tomato genotypes collected from various sources and were laid out in Randomized Block Design (RBD) with three replications at College of Agriculture, Vellayani, Kerala during October 2013 to April 2014. The experiment was conducted in saw toothed type naturally ventilated polyhouse of gutter height of $5 \mathrm{~m}$ high, gutter slop of $2 \%$ and size $1000 \mathrm{~m}^{2}(50 \mathrm{~m} \times 20 \mathrm{~m})$ located in Instructional farm, Vellayani. Transplanting was done at a spacing of $75 \times 60 \mathrm{~cm}$ in raised beds. Data were recorded on various characters. Analysis of variance was done based on RBD as suggested by Panse and Sukhatme (1967) for each of the characters separately. Mahalanobis generalized distance $\left(D^{2}\right)$ was used to determine the degree of divergence and the genotype were grouped into clusters following Tocher's method (Rao, 1952).

\section{Results and Discussion}

In the present study, 40 genotypes of tomato were subjected to $\mathrm{D}^{2}$ analysis based on all the characters studied. The genotypes were grouped into eight clusters on the basis of relative magnitude of $\mathrm{D}^{2}$ values (Table 1 ). C. The grouping of genotypes into eight clusters indicated the presence of genetic diversity among the genotypes. These findings are in close conformity with those of Sharma et al. (2009), Basavaraj et al. (2010), Evgenidis et al. (2011), Thamir et al. (2014) and Dar et al. (2015).

Cluster I had the maximum number of genotypes (24), followed by cluster I1 (10) and other clusters had only one genotype. The composition of clusters of heterogenous geographic origin indicated that, the strains were distributed among the different clusters randomly irrespective of their geographical origin. This indicates the fact that there was no parallelism between genetic diversity and geographical divergence in the tomato crop. Similarly, Chernet et al. (2014) clustered 36 genotypes into six distinct clusters and Iqbal et al. (2014) grouped 47 tomato genotypes into five clusters. Wide genetic diversity was observed among the genotypes which were grouped into five clusters by Tocher's method based on $\mathrm{D}^{2}$ values. (Meena and Bahadur, 2015).

The $\mathrm{D}^{2}$ technique measures the forces of differentiation at two levels, namely intracluster and intercluster level and thus helps in the selection of genetically divergent parents for exploitation in hybridization programmes. The intracluster distance shows divergence among the genotypes within a cluster, whereas the intercluster distance expresses relative divergence among the clusters. The average inter and intra cluster distances were estimated based on total $\mathrm{D}^{2}$ values as given in table 2.

The intracluster distances seen to be lower than intercluster distances. Cluster II had the highest intracluster distance (20.46) 
followed by cluster I (18.44). All the other clusters had zero intra cluster distance as they included only one genotype.

The highest intercluster distance was observed between clusters VII and VIII (56.42), followed by clusters IV and VIII
(50.05), clusters VII and VI (49.69) and clusters V and VIII (47.80). Cluster I had least proximity to clusters VII and VIII. Cluster II exhibited least proximity with clusters IV, VIII and VII. Cluster III had more distance with clusters VIII and VI.

Table.1 Clustering Pattern of 40 Tomato Genotypes

\begin{tabular}{|c|c|l|}
\hline $\begin{array}{c}\text { Cluster } \\
\text { number }\end{array}$ & $\begin{array}{l}\text { Number } \\
\text { of } \\
\text { genotypes }\end{array}$ & Genotypes \\
\hline I & 24 & $\begin{array}{l}\text { LE 5, LE 6, LE 8, LE 10, LE 11, LE 12, LE 13, LE 15, LE 18, LE 20, } \\
\text { LE 2, LE 22, LE 23, LE 25, LE 27, LE 28, LE 29, LE 30, LE 31, LE } \\
\text { 32, LE 33, LE 36, LE 37 and LE 49 }\end{array}$ \\
\hline II & 10 & $\begin{array}{l}\text { LE 4, LE 7, LE 14, LE 16, LE 17, LE 19, LE 26, LE 38, LE 39 and LE } \\
54\end{array}$ \\
\hline III & 1 & LE 56 \\
\hline IV & 1 & LE 24 \\
\hline V & 1 & LE 3 \\
\hline VI & 1 & LE 53 \\
\hline VII & 1 & LE 1 \\
\hline VIII & 1 & LE 2 \\
\hline
\end{tabular}

Table.2 Average Intra and Inter Cluster Distances (D2 values)

\begin{tabular}{|c|c|c|c|c|c|c|c|c|}
\hline Clusters & I & II & III & IV & V & VI & VII & VIII \\
\hline I & 18.44 & 27.61 & 24.66 & 22.67 & 27.59 & 33.06 & 34.71 & 42.02 \\
\hline II & & 20.46 & 25.22 & 38.28 & 27.06 & 29.75 & 34.41 & 34.48 \\
\hline III & & & 0.00 & 33.90 & 21.53 & 37.13 & 21.25 & 45.97 \\
\hline IV & & & & 0.00 & 33.32 & 40.43 & 38.30 & 50.05 \\
\hline V & & & & & 0.00 & 40.31 & 19.64 & 47.80 \\
\hline VI & & & & & & 0.00 & 49.69 & 24.60 \\
\hline VII & & & & & & & 0.00 & 56.42 \\
\hline VIII & & & & & & & & 0.00 \\
\hline
\end{tabular}

Diagonal elements - intracluster values

Off diagonal elements - intercluster values 
Table.3 Percent Contribution of Various Characters for Divergence in Tomato

\begin{tabular}{|c|c|c|c|}
\hline Sl. No. & Characters & Times ranked $1^{\text {st }}$ & $\begin{array}{l}\text { Contribution } \\
(\%)\end{array}$ \\
\hline 1 & Plant height (m) & 16 & 2.05 \\
\hline 2 & Height at flowering $(\mathrm{cm})$ & 20 & 2.56 \\
\hline 3 & Leaves preceeding first inflorescence & 5 & 0.64 \\
\hline 4 & Internodal length $(\mathrm{cm})$ & 11 & 1.41 \\
\hline 5 & Leaf length $(\mathrm{cm})$ & 6 & 0.77 \\
\hline 6 & Leaf width $(\mathrm{cm})$ & 4 & 0.51 \\
\hline 7 & Days to flowering & 0 & 0.00 \\
\hline 8 & Days to fruitset & 0 & 0.00 \\
\hline 9 & Flowers cluster $^{-1}$ & 0 & 0.00 \\
\hline 10 & Inflorescence plant $^{-1}$ & 1 & 0.13 \\
\hline 11 & Fruitset (\%) & 7 & 0.90 \\
\hline 12 & Pollen viability (\%) & 34 & 4.36 \\
\hline 13 & Truss plant $^{-1}$ & 112 & 14.36 \\
\hline 14 & Fruits truss ${ }^{-1}$ & 37 & 4.74 \\
\hline 15 & Fruits plant $^{-1}$ & 20 & 2.56 \\
\hline 16 & Fruit length $(\mathrm{cm})$ & 95 & 12.18 \\
\hline 17 & Fruit girth $(\mathrm{cm})$ & 46 & 5.90 \\
\hline 18 & Fruit weight $(\mathrm{g})$ & 88 & 11.28 \\
\hline 19 & Length breadth ratio & 3 & 0.38 \\
\hline 20 & Yield plant $^{-1}(\mathrm{~g})$ & 77 & 9.87 \\
\hline 21 & TSS $\left({ }^{\circ}\right.$ Brix $)$ & 1 & 0.13 \\
\hline 22 & Beta carotene $\left(\mathrm{mg} 100 \mathrm{~g}^{-1}\right)$ & 25 & 3.21 \\
\hline 23 & Lycopene (mg 100g $\left.{ }^{-1}\right)$ & 159 & 20.38 \\
\hline 24 & Ascorbic acid $\left({\left.\mathrm{mg} 100 \mathrm{~g}^{-1}\right)}\right.$ & 13 & 1.67 \\
\hline
\end{tabular}

The minimum intercluster distance was observed between clusters V and VII (19.64) indicating a close relationship among the genotypes included. Average inter and intracluster distances revealed that in general, inter-cluster distances were much higher than those of intracluster distances, suggesting homogeneous and heterogeneous nature of the genotypes lines within and between the clusters respectively. These results are in accordance with the findings of Mahesha et al. (2006), Sekhar et al. (2008), Reddy et al. (2013) and Meena and Bahadur (2015) in tomato.

Depending upon the breeding objective, the potential lines to be selected from different clusters as parents in a hybridization program may be based on genetic distance. In accordance to the findings, Hazra et al. (2010) and Meena and Bahadur (2015) reported that the clustering pattern could be utilized in choosing parents for cross combinations likely to generate the highest possible variability for various economic characters.

The proportional contribution of characters towards the total $\mathrm{D}^{2}$ statistics was different, which is represented in table 3. Lycopene content $(20.38 \%)$ and truss per plant $(14.36 \%)$ were the maximum contributors towards total divergence followed by fruit length (12.18\%), fruit weight (11.28\%) and 
yield per plant $(9.87 \%)$. Fruit girth $(5.90 \%)$, fruits per truss $(4.74 \%)$, pollen viability $(4.36 \%)$, beta carotene $(3.21 \%)$, fruits per plant $(2.56 \%)$ and height at flowering $(2.56 \%)$ were moderately contributing towards total divergence. These results indicated that the rest of the characters were not contributing much towards the total divergence.

In conclusion of the present study forty tomato genotypes were assessed to know the value and magnitude of genetic divergence using Mahalanobis $\mathrm{D}^{2}$ statistics. A wide genetic diversity was observed among the genotypes and was grouped into eight clusters. The clustering pattern indicated that the geographic diversity need not necessarily be related to genetic diversity. The present study including forty tomato genotypes under protected conditions revealed that cluster VII had superior performance for yield. For the quality characters of tomato clusters VI, VII and VIII were promising. Genotypes in these clusters are proposed for hybridization to get heterotic hybrids in $\mathrm{F}_{1}$ generation and some promising transgressive segregants in $F_{2}$ generation. Therefore, selection of divergent parents based on cluster distance is recommended for getting good hybrids or segregants in tomato under protected conditions.

\section{Acknowledgement}

The first author (Lekshmi S. L.) is grateful to the Kerala State Council for Science, Technology and Environment (KSCSTE), Kerala for the award of research fellowship programme.

\section{References}

Basavaraj, N.S., Patil, B.C., Salimath, P.M. Hosamani, R.M., Krishnaraj, P.U.
2010. Genetic divergence in tomato (Solanum lycoperiscon [Mill.] Wettsd.). Karnataka J. Agri. Sci., 23(3): 508-539.

Chernet, S., Belew, D. and Abay, F. 2014. Genetic variability and association of characters in tomato (Solanum lycopersicum L.) genotypes in northern Ethiopia. Int. J. Agri. Res., 8(2): 67-76.

Evgenidis, G., Traka-Mavrona, E., Koutsika-Sotiriou, M. 2011. Principal component and clusters analysis as a tool in the assessment of tomato hybrids and cultivars. Int. J. Agri., 6(23): 334-339.

Dar, R.A., Sharma, J.P., Mushtaq, A. 2015. Genetic diversity among some productive genotypes of tomato (Lycopersicon esculentum Mill.). Afri. J. Biotechnol., 14(22): 18461853.

Hazra, P., Sahu, P.K., Roy, U, Dutta, R., Roy, T., Chattopadhyay, A. 2010. Heterosis in relation to multivariate genetic divergence in brinjal (Solanum melongena). Indian J. Agri. Sci., 80: 119-124.

Iqbal, Q., Saleem, M.Y., Hameed, A., Asghar, M. 2014. Assessment of genetic divergence in tomato through Agglomerative hierarchical clustering and Principal component analysis. Pakisthan J. Bot., 46(5): 1865-1870.

Mahesha, D.K., Apte, U.B., Jadhav, B.B. 2006. Studies on genetic divergence in tomato (Lycopersicon esculentum Mill.). Crop Res., 32(3): 401-402.

Meena, O.P., Bahadur, V. 2015. Breeding potential of indeterminate tomato (Solanum lycopersicum L.) accessions using $\mathrm{D}^{2}$ analysis. SABRAO J. Breeding and Genetics, 47(1): 49-59.

Panse, V.G., Sukhatme, P.V. 1967. 
Statistical Methods for Agricultural Workers. Indian Council of Agricultural Research, New Delhi. Pp. $152-161$.

Reddy, B.R., Reddy, D.S., Reddaiah, K., Sunil, N. 2013. Studies on genetic variability, heritability and genetic advance for yield and quality traits in Tomato (Solanum lycopersicum L.). Int. J. Curr. Microbiol. Appl. Sci., 2(9): 238-244.

Sekhar, L., Prakash, B.G., Salimath, P.M., Sridevi, O., Patil, A.A. 2008. Genetic diversity among some productive hybrids of tomato (Lycopersicon esculentum Mill.). Karnataka J. Agri. Sci., 21(2): 264-265.
Sharma, J.P., Singh, A.K., Satesh, K., Sanjeev, K. 2009. Identification of traits for ideotype selection in tomato. Mysore J. Agri. Sci., 43: 222-226.

Rao, C.R. 1952. Advanced Statistical Methods in Biometrics Research John Wiley and Sons, New York, pp. 357-369.

Thamir, A.J., Al-Saadi, A.H., Abbass, M.C. 2014. Genetic diversity of some tomato Lycopersicon esculentum Mill varieties in Iraq using random amplified polymorphic DNA (RAPD) markers. J. Babylon Univ. Pure Appl. Sci., 9(22): 2342-2351.

\section{How to cite this article:}

Lekshmi, S. L., and Celine, V. A. 2016. Genetic Diversity Studies in Tomato (Solanum lycopersicum L.) Under Protected Conditions. Int.J.Curr.Microbiol.App.Sci. 5(4): 212-217. doi: http://dx.doi.org/10.20546/ijcmas.2016.504.026 